\title{
Classic Exodus commentary still relevant
}

\section{Book Title:}

Exodus: An introduction and commentary (Tyndale Old Testament Commentaries)

Book Cover:

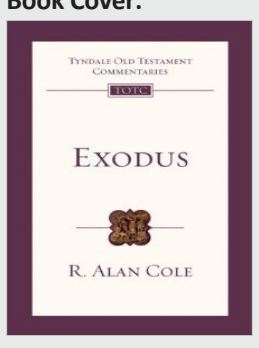

Author:

R. Alan Cole

ISBN:

978-0830842025

Publisher:

Inter-Varsity Press Leicester/ Downers Grove, England

[1973] 2008, pp. 239

US\$16.00 Paperback*

*Book price at time of review

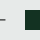

Review Title:

Classic Exodus commentary

still relevant

Reviewer:

Stephen J. Bennett ${ }^{1}$

\section{Affiliation:}

${ }^{1}$ Nyack College, New York,

United States of America

Email:

stephen.bennett@nyack.edu

Postal address:

1 South Boulevard, Nyack,

New York 10960

United States of America

How to cite this book review:

Bennett, S.J., 2014, 'Classic

Exodus commentary still

relevant', Koers - Bulletin for

Christian Scholarship 79(1),

Art. \#2109, 2 pages. http://

dx.doi.org/10.4102/koers.

v79i1.2109

\section{Copyright:}

(C) 2014. The Authors.

Licensee: AOSIS

OpenJournals. This work

is licensed under the

Creative Commons

Attribution License.

Read online:

口iras Scan this $Q R$ code with $y$ smart phone or mobile device mobile device to read online.
R. Alan Cole published Exodus: An introduction and commentary in 1973. This commentary has remained in print for four decades, partly due to its place in the series Tyndale Old Testament Commentaries. Consistent with the other volumes in the series, it has a significant introduction (41 pages) ${ }^{1}$ and, although it is a small book, there is commentary of at least a sentence or paragraph on most verses, and important verses are given up to a page of commentary.

Cole's introduction has a helpful priority of theology over historical matters. He devotes 22 pages to the theology of the Exodus under the headings 'The God Who Controls History', 'I Am YHWH', 'The God Who Is Holy', 'The God Who Remembers', 'The God Who Acts in Salvation', 'The God Who Acts in Judgment', 'The God Whose Anger May Be Averted', 'The God Who Speaks', 'The God Who Is Transcendent', and 'The God Who Lives among His People'. Cole seems to neglect the important category of the God who sees and hears (although choices of priority inevitably must be made in an introduction like this; Ex 3:7). Cole also leaves 'creation' out of his list of five major themes in the Pentateuch (p. 12 [p. 15]). Nevertheless, Cole does a good job of summarising the theology of a book which presents the problem of disclosing the character of Yahweh to Moses, the people of Israel, and Pharaoh.

Cole's section on the holiness of God is particularly helpful. He shows the relational and moral nature of holiness and in memorable wording describes the law as the verbal expression of God's holiness, the tabernacle as the visible parable of it, and the people of Israel as the walking illustration of it (p. 23 [p. 27]). Cole is at pains to show a connection between the exodus and Christian redemption, but he also defines salvation in Old Testament terms of military and political realities, including the exodus 'as the supreme example' (pp. 17-18, 27-29 [pp. 20-21, 31-34]).

At one point, Cole's theological interpretation seems unlikely to resonate with the general outlook of the Old Testament. He claims that 'if God still "remembers" the patriarchs, then they must still exist' (pp. 26-27 [p. 30]). Elsewhere the Old Testament does little to suggest a meaningful relationship with God from Sheol or after death (Ps 6:5 [MT 6:6]).

Although Cole gives priority to theological matters, he also devotes three excurses to the date of the exodus, the site of the 'Red Sea', and the sources of Exodus. Naturally, Cole's archaeological evidence is dated, but he nevertheless gives a balanced account of historical matters, admitting uncertainty when there is a lack of data. He writes:

It is not essential that we know the numbers, or route, or date of the exodus. It is enough that, with later Israel, we know and believe that such an event happened, and that we too interpret it as a saving act of God. (p. 16 [pp. 18-19])

Cole claims that the 'essential historicity of Moses and of his work (at least in broad outline) would now be widely accepted' in biblical scholarship (p. 15 [p. 18]). This viewpoint can no longer be sustained and attitudes to historicity were beginning to change in the 1970s (see Nicholson 1986; Perlitt 1969; Thompson 1974; Van Seters 1975).

In the commentary, Cole gives helpful explanations of most verses and includes insights from Hebrew, offering a literal rendering where appropriate (e.g. birthstool is literally two stones, Ex 1:16, p. 55 [p. 61]). He offers a helpful integrated view of theological and scientific explanations, which others may see as contradictory. For example, Exodus 14 attributes the parting of the Red Sea to the action of God and the natural phenomenon of wind (Ex 14 does not mention tide). Cole suggests that these 'are not mutually exclusive explanations, nor even equally valid alternative explanations. To the Hebrew they are essentially the same explanation, phrased differently' (p. 77 [p. 84]).

The Tyndale format does not have a section for application, but Cole does make some attempt to apply the theology of Exodus to contemporary Christian life. For example, on page 235

1.Forty-five pages in the 2008 printing (which has been re-paginated). 
[pp. 244-245] he uses the phrases 'Here again is a message for us today' and 'God deliver any of us from such a frustration'.

Overall, Cole's commentary is a useful shorter introduction to the text of Exodus. There is little documentation and Cole points the reader to other works (usually Hyatt 1971) when further information may be desired. He is conversant with a broad spectrum of scholarship and engages different ideas, but does not usually go into great detail. He also mentions Hebrew nuances and sometimes includes the Hebrew word under discussion (transliterated). These features make the book accessible to non-specialists who would be distracted by too much technical detail and documentation.
Some editing errors were corrected for the 2008 printing, but a couple remain: 'Siniai' (for 'Sinai', p. 25 [p. 29]); 'peal' (for 'deal', p.183 [p. 191]).

\section{References}

Hyatt, J.P., 1971, Commentary on Exodus, Oliphants, London.

Nicholson, E.W., 1986, God and His people: Covenant and theology in the Old Testament, Oxford University Press, Oxford.

Perlitt, L., 1969, Bundestheologie im alten Testament, Neukirchener Verlag, Neukirchen-Vluyn.

Thompson, T.L., 1974, The historicity of the patriarchal narratives: The quest for the historical Abraham, Walter de Gruyter, Berlin.

Van Seters, J., 1975, Abraham in history and tradition Yale University Press, New Haven. 